総 説

\title{
日本におけるイオン交換技術の発展について
}

\author{
清水 博 \\ 技術士（清水コンサルタントオフィス） \\ \%112 東京都文京区白山4-21-15（自宅）
}

(1993年7月 2 日受理)

\section{0 年代}

1980年に半導体工場で世界初のクローズドシステ ムによる超純水製造プラントが建設された

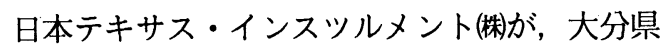
日出工場において, 半導体の量産により発生する 廃水による環境の保全と地元漁協の不安を除くた め, 排水を全量回収し, 超純水として再利用する 完全クローズドシステムを採用することを決定し た。

オルガノ株はその全システムを計画したが，世 界で初めての試みであるため, 不明要素が多かっ た。特に半導体製造工程の排水中に多量に含まれ る有機溶剤系洗浄排水や高 TOCの弱酸系排水中の 有機物の処理には, ナイロンの製造原料の合成工 程で使用される強力は光酸化方式を用いることを 発案し, 超純水化工程に新たな不純物負荷を極力 与えないように, $\mathrm{H}_{2} \mathrm{O}_{2}$ の存在下に紫外線（波長 $365 \mathrm{~nm}$ ）を照射する酸化工程により有機物を $\mathrm{CO}_{2}$ や $\mathrm{H}_{2} \mathrm{O}$ に分解する方式を創案した。しかしそのよ うな参考文献は当時全く無く, 日本テキサス・イ ンスッルメント(株)の協力を得て, パイロットプラ ント試験により諸問題を解明しながら, 全計画の 立案を推進して処理技術を完成した ${ }^{118), 1199} 。$

世界最初のクローズドシステムによる超純水製
造プラントは，1980年に日出工場に建設されて運 転に入り，実用化に成功した ${ }^{118), 119) 。 ~}$

このシステムは, 生活廃水をも含む全排水を回 収処理して，排水を一滴も工場外に出さず，超純 水化して再使用するもので，水が外に出るところ は冷房用のクーリングタワーからの発生水蒸気 之, 濃厚液の濃縮固形化物中の含有水分だけであ った（図1参照) ${ }^{120)}$ 。

この完全クローズドシステムには, 排水中の酸 などを除去する弱塩基性アニオン交換樹脂を用い た 2 床式脱塩水製造装置, 有機物を酸化分解する $\mathrm{H}_{2} \mathrm{O}_{2}$ 添加紫外線照射酸化装置と, 残留 $\mathrm{H}_{2} \mathrm{O}_{2}$ ・酸化 途上物質などを除去する活性炭吸着装置, 真空脱 気塔，無機・有機酸などを除去する混床式純水製 造装置, 紫外線殺菌器, 微量の無機・有機物を除 去する逆浸透装置・混床式ポリシャ一, 精密瀘過 器などの使用, および濃厚廃液を濃縮する蒸発 缶, 並びにグラインド工程排水などを処理する脱 水瀘過濃縮装置・限外瀘過装置など, 多種多様の 処理設備が使用された。

その結果, 廃水を工場外に全く出さないことに より，環境污染の問題を完全に解決したばかりで なく，給水の補給率を極めて低い值に維持するこ とが出来た。 


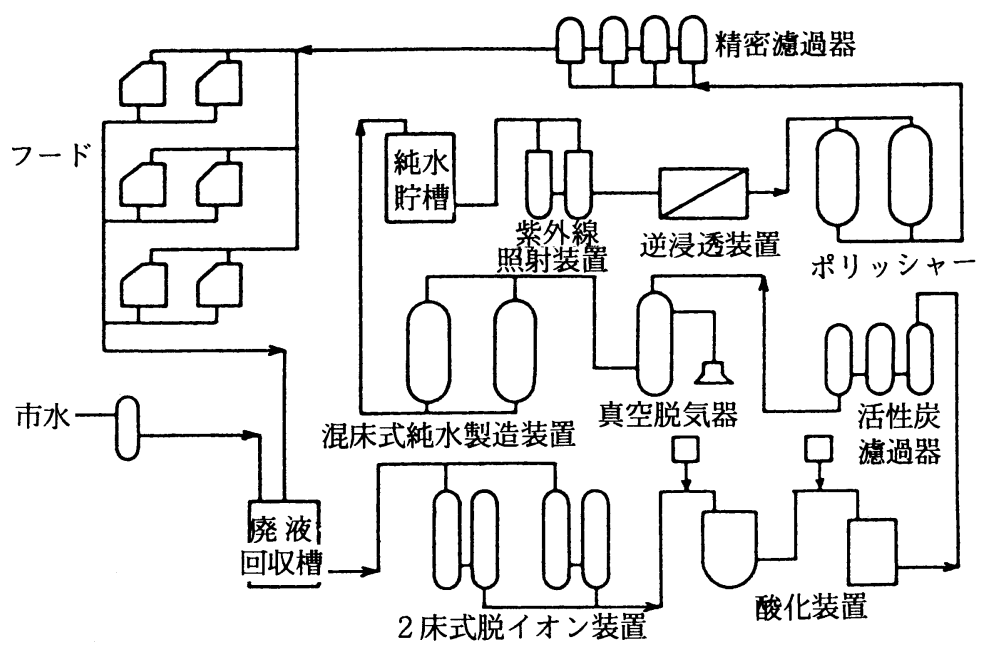

図1 半導体製造工場に建設の排水を回収してクローズド化した超純水製造シ ステムのフローシート

これ以降, 日本テキサス・インスツルメント(森) は数セットの同様システムを各工場に建設した。

このような方式のクローズドシステム（図 2参

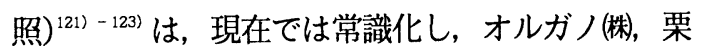
田工業(侏)，野村マイクロ・サイエンス(怢)な゙によ

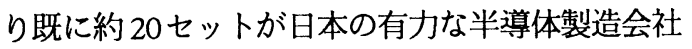
に建設されて, 成功裏に運転されており, 環境污 染の防止と, 工業用水の補給率の低減化（補給率 は約 10\%以下）などに役立っている。

1982年に世界で初めて本格的なイオン交換綫維の 工業生産が開始された

(㖉ニチビは, ポリビニルアルコール系高速イオ ン交換瀻維の製造について, 工業技術院繊維高分 子材料研究所之協同研究を行い, その成果を基に して新技術開発事業団の委託を受けて，1980年か ら 2 年間実証試験を実施したが，1982年に到り成 功認定を受け, 月産 5 トンの強酸性カチオン交換 繊維の製造プラントを完成して，世界で初めてイ オン交換繊維の工業生産と販売を開始した ${ }^{124)-127) 。 ~}$

製法は，ポリビニルアルコール(PVA)に脱水触 媒を加えて乾式紡系して系条を形成し，所定長に カットした後, 空気中で焼成して脱水反応により
PVA 分子内にポリエン構造を生成させる。この焼 成瀻維を濃硫酸で処理してスルホン酸基を導入 し, 水洗, 中和, - 純水洗浄を行い, 脱水して製品 とする（標準製品の商品名はニチビ IEFSC3050) ${ }^{126)-128)}$ 。

標準製品につき，その性質と性能を表 $2^{(26)-128)}$ に, 顕微鏡写真を写真 33 に示す。なお表 2 には, 後述する同社製の強塩基性アニオン交換繊維およ びキレート繊維の性質と性能についても示す。

粒子状のイオン交換樹脂に比べたこのイオン交 換繊維の利点は, 下記の通りである ${ }^{126)-128) 。 ~}$

1）形状の均一なイオン交換体が容易に製造出来 ること。

最近は, イオン交換性能を向上させるため に，イオン交換体の粒径が均一なものの要求 が高まっているが, イオン交換繊維では形状 均一のものが容易に製造出来る。

2）反応速度が速いこと。

粒状のイオン交換樹脂は直径が通常 300〜 $800 \mu \mathrm{m}$ と大きく, プレコート用の微粉樹脂 でも 40〜 $250 \mu \mathrm{m}$ であるのに対し，このイオ ン交換繊維は断面の直径は $10 \sim 30 \mu \mathrm{m}$ でイ オン交換樹脂に比し遙かに微小であるから, 


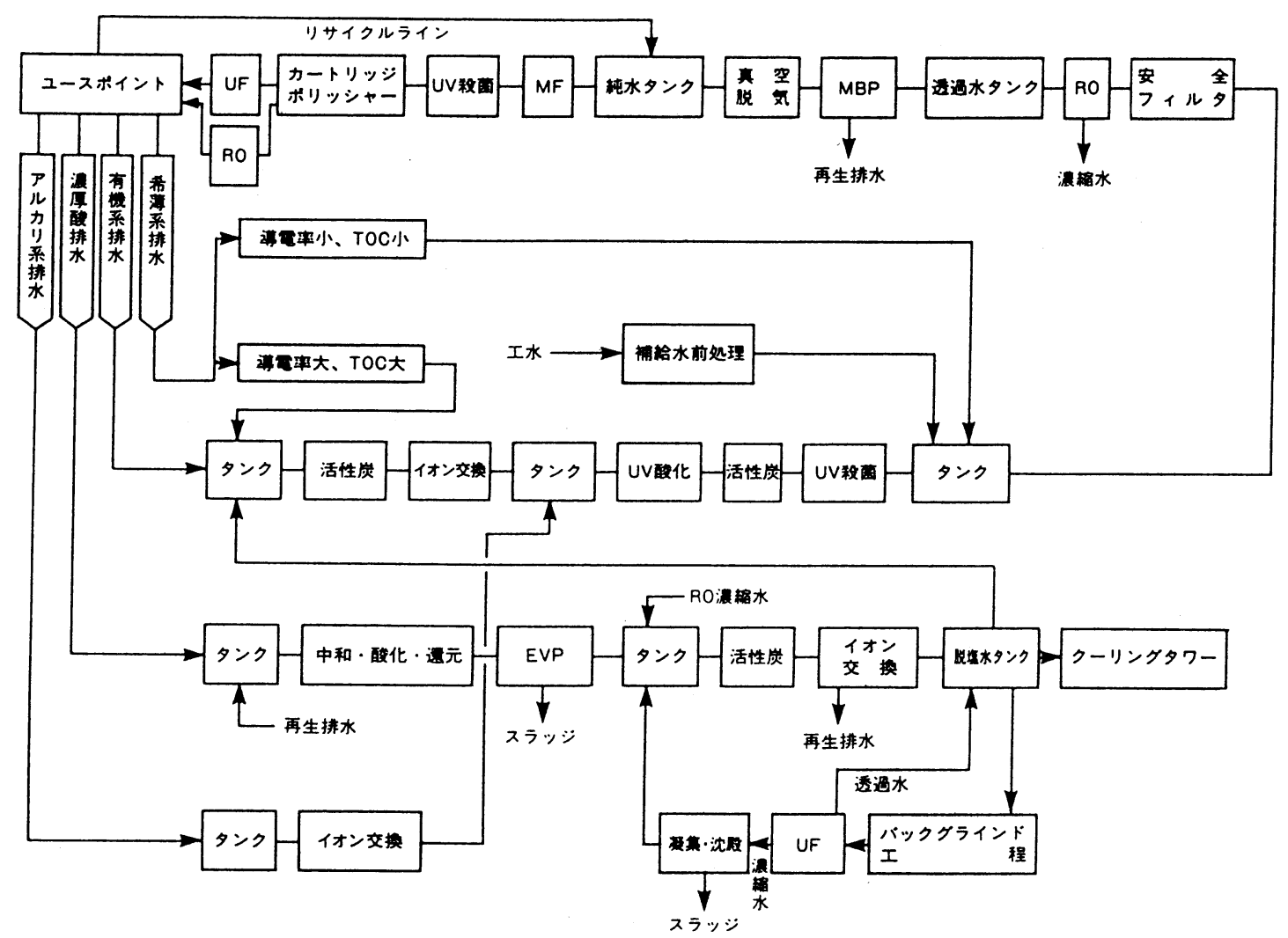

図2 半導体製造工場の排水の回収を組み込んだクローズド型超純水製造シス テムの一般(例'21)

表面積が大きく，短時間に反応が完結する。 したがって, 吸着・溶離の速度が 1 桁程度大 で，大巾な処理時間の短縮が図れる利点があ る。

また， $\mathrm{Ca}$ 型のカチオン体を $1 \mathrm{~N}-\mathrm{NaCl}$, SV100/h で再生する場合, カチオン交換繊維 では理論值の 4倍の通薬で $100 \%$ 再生される が，通常のゲル型カチオン交換樹脂では理論 值の僅か約 60\% しか再生されず, 通薬量を 理論値の3倍に増量しても約 $90 \%$ しか再生出 来ない。

以上のことから，イオン交換繊維は高流速 通水時のイオンの吸・脱着容量が大で，また 表面積が大きいので高分子の除去性能が大 で, 静的イオン交換容量は粒状イオン交換樹
脂に比し大約 $1 / 2$ に過ぎないが，実用上の動 的イオン交換容量は粒状イオン交換樹脂より かえって遙かに大である。

3）自由な形状のモジュールが容易に製造出来る ので用途が広いこと。

紐状, 編状, 不織布状, 紙状, フェル卜状 など，各種のモジュールの製造が可能である から，例えばガスの処理など，粒状態のイオ ン交換樹脂では使用が困難であった用途にも 容易に使用出来る可能性がある:29)。

次に, 強塩基性アニオン交換繊維については, ポリビニルアルコール繊維を母体として, ブロム アセタール化し, 架橋し, 第三級アミンで四級化 して製造したアニオン交換繊維を開発し，1992年 に製造設備を設けて, 製品のニチビIEF-SA（表 
表 2 (侏)ニチビ製イオン交換織維とキレート繊維の性質と性能 (標準製品) ${ }^{126)}$ - 128)

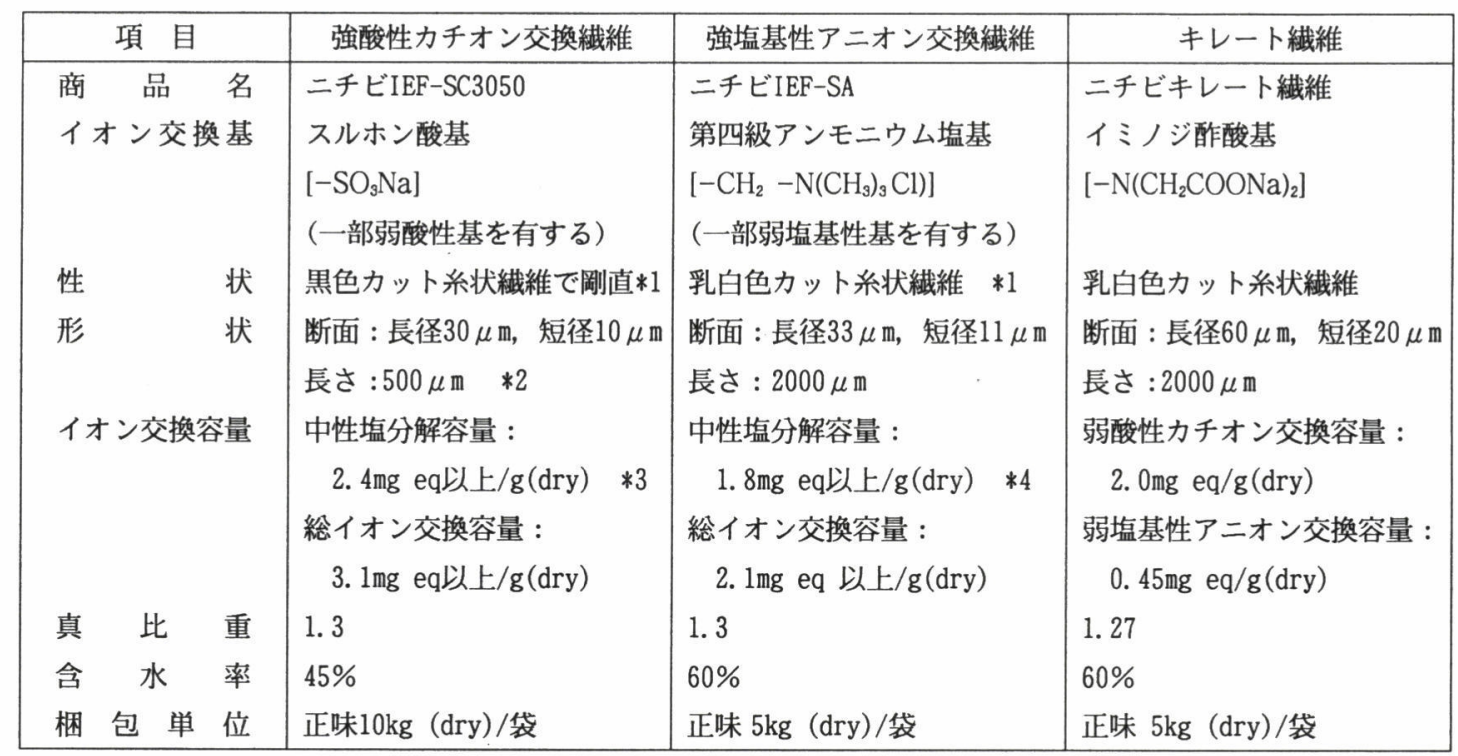

*1 ステープル状，フィラメント状，および不織布状で供給も可能。

*2 長さ $250 \mu \mathrm{m}(\mathrm{SC}-3025)$ と, $1500 \mu \mathrm{m}$ あも(SC-30150) もある。

*3 通常の強酸性力チオン交換樹脂の中性塩分解容量 $4.3 \sim 4.4 \mathrm{mg}$ eq/g(dry)の約 $1 / 1.8$

*4 通常のI型強塩基性アニオン交換樹脂の中性塩分解容量3. $7 \sim 4.2 \mathrm{mg}$ eq/g(dry)の約 $1 / 2.1 \sim 1 / 2.3$

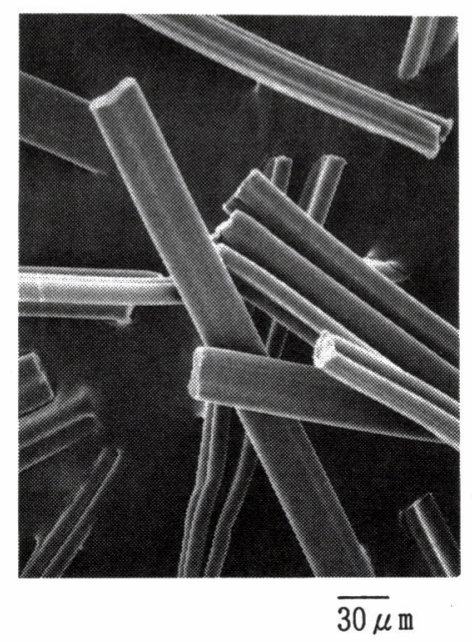

(侏)ニチビ提供

写真 33 強酸性カチオン交換織維ニチビ IEFSC3050 の顕微鏡写真

2参照）の製造販売を行っている ${ }^{127)}$ 。

またキレート繊維については, ポリビニルアル コール絾維を母体とするイミノジ酢酸型のものを
小規模で製造販売している。その製法は, ポリビ ニルアルコールの熱処理糸に硫酸を含侵して乾燥 させた後, エピクロールヒドリン中で $40^{\circ} \mathrm{C} に 1$ 時 間処理してエーテル化を行い, 次にホルマリンで アセタール化して耐熱性とし, 最後に15\%イミノ 济酷酸水溶液で $80^{\circ} \mathrm{C} に 20$ 時間処理して, イミノ シ䣷酸基を導入したものである。製品（二チビイ オン交換繊維）の性状と性能を表 2 に示す ${ }^{127) 。 ~}$

このキレート纎維および弱塩基性アニオン交換 繊維については, 現在はユーザーの希望により少 量生産して販売している状態であるが, 将来は製 造設備を拡充する計画である ${ }^{127) 。 ~}$

このようなイオン交換繊維やキレート繊維は, 一般的に通常のイオン交換樹脂やキレート樹脂で は処理困難な下記の様な場合に有効に利用される 可能性が高(125) - 127)。

1）大量の希薄液を短時間に処理する必要性があ る場合。

例えば, 原子力発電所の放射性復水のイオ 
ン交換濾過装置や，ラド系排水の処理で，こ れまでの微粉末イオン交換樹脂をプリコート する濾過器において, イオン交換繊維を混合 してプリコートすると, 濾過抵抗の増加率が 小となり, 濾過材の寿命が顕著に延長して, 放射性廃棄物の生成量が著しく減少す

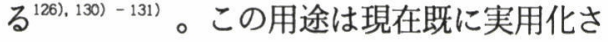
れている。

2）難分離性物質を分離・精製する場合。

例えば希土類金属の分離・精製, $\mathrm{Nb}-\mathrm{Ta}$ の分離・精製，アミノ酸の分離精製などが研 究されており，それぞれ成果を上げている （写真 34 参照）。

3）イオン交換繊維やキレート繊維をモジュール

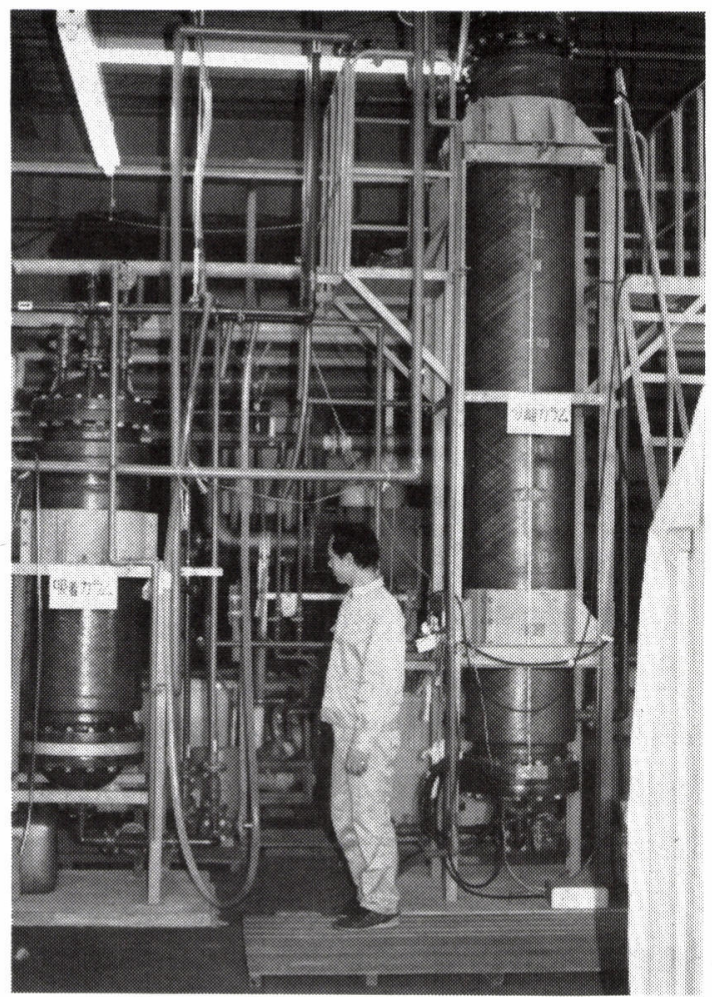

（侏)ニチビ提供）

写真 34 ニチビIEF-SC3050を使用した希土類分離 のパイロットプラント

（累計 3 年間の運転で, 圧力損失增大や分離 性能低下はなかった）
化することにより開発される新用途。

種々のモジュールの形態と，それぞれの適 用用途の例を次に示す。

(1) カット糸状 : 充填層用。

(2) 紐状：カートリッジフィルター用巻 紐。

（3) 編物・織物・不織布状 : 膜状イオン交 換体の補強など。

(4) 紙状 : 分析用濾紙, 連続自動測定用濾 紙。

(5) フェルト状 : エアフィルター, フィル タープレス用滤過材，気相・液相での 触媒, 気相での脱塩など。

(6) フロック加工 : エアフィルター。

以上のうち，紙状に加工した分析用濾紙の応用 例を次に示す ${ }^{126), ~ 132) ~-~ 134) 。 ~}$

住友化学工業(㑣は，1978年に分析用のイオン交 換濾紙とキレート濾紙（商品名エクスパピール） を開発して上市した（1989年からは(㑣)住化分析セ ンターで製造販売を行っている $)^{133) 。}$

この濾紙に試料を通して微量元素を吸着させ, 風乾した濾紙を直接に蛍光 $X$ 線分析装置で検出定 量するか，または溶離して得られる溶出液を原子 吸光分析装置で検出定量するのに使用されてい る。

この濾紙による分析法は, イオンの捕捉速度が 通常のイオン交換樹脂の $100 \sim 1000$ 倍に達し，分 析時間は検液採取から分析まで 2 時間に短縮され る。検液中のイオン濃度としては ppt〜 ppbオー ダーの高感度分析が可能であり, 多元素の同時分 析が出来る。また, 検液を現場で滤過処理し, 滤 紙だけを分析室に持ち帰ればよく, 検液の輸送や 保存の必要が無いなど, 多くの利点がある ${ }^{133)}$ - 134)。 現在，このイオン交換濾紙は原水力発電所などで 常用されている。

1990 年には, 東レ(㧣ももオン交換繊維の商品 (IONEX)の製造販売を行うようになった。

東レ(㑣)のイオン交換瀻維は，イオン交換樹脂の 
母体として現在汎用されているポリスチレンを主 成分とする “海”成分と，ポリエチレンを補強材 とする “島”成分として製系して, 多芯海島型複 合繊維（写真 35 参照 $)^{135)}$ - 137) を先ず製造する。

次にこれを必要な形態に加工した後, パラホル ムアルデヒド——硫酸溶液中で架橋して得られる 架橋ポリスチレン瀻維を母体として，スチレン系 イオン交換樹脂の場合と同様に, これにスルホン 酸基やトリメチルアンモニウム基を導入して, 強 酸性力チオン交換繊維や強塩基性アニオン交換繊 維としたものである（写真 36参照）。IONEXの 性質や性能などを表 3 に示す ${ }^{138)}$ 。

IONEXのカットファイバーを紙状に加工して作 った強酸性力チオン交換濾紙と, 強塩基性アニオ ン交換濾紙の商品(IONEX RX-1)は，1989年に上
市された

これらのイオン交換繊維やイオン交換濾紙の特 徵は, 繊維の母体がイオン交換樹に汎用される架 橋ポリスチレンに近いものなので, 既存の用途分 野におけるイオン交換樹脂の欠点を, このイオン 交換繊維で置き換えて改善することが比較的容易 なことである。

カットファイバー状のIONEXは, 原子力発電所 の復水浄化装置に用いるプレコート式濾過器の粉 末イオン交換樹脂に混合して使用することで，そ の濾過器の寿命を数倍に延長させる用途に実用化

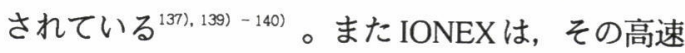
の反応性や, 高分子, 微生物, 微粒子などに対す る高吸着性などを利用して, 低TOCで高品質の超 純水を得る超純水製造装置（トレピュア）（写真 37

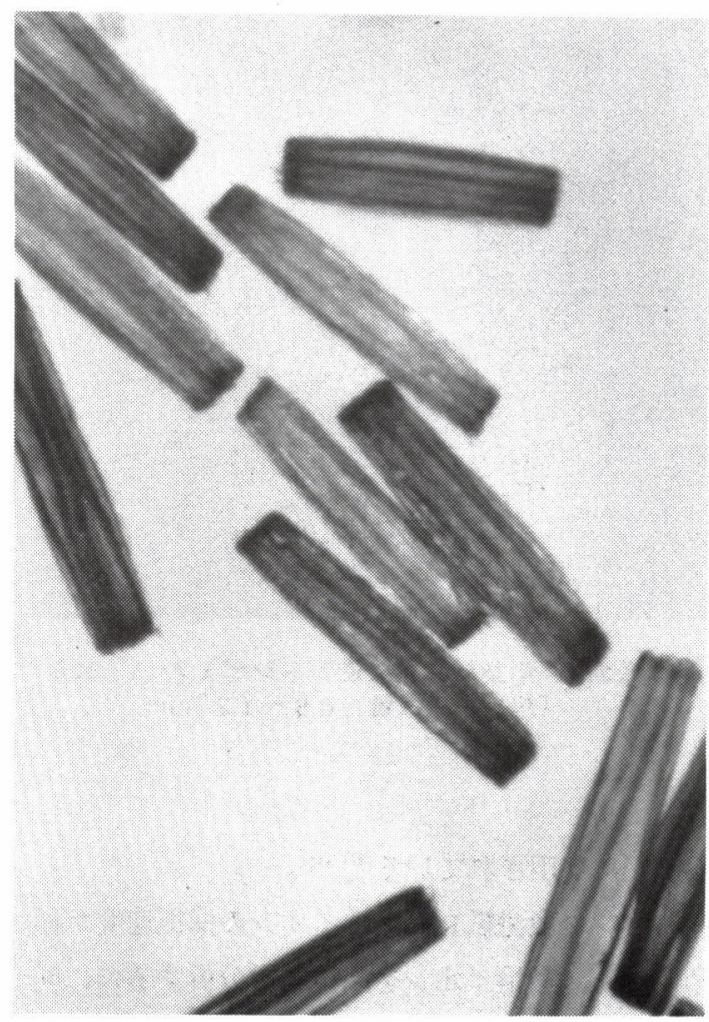

（東レ(株提供）

写真 36 強酸性カチオン交換䋛維IONEX TIN-110 の顕微鏡写真 
表3 東レ(侏製イオン交換緎維商品の性質と性能 ${ }^{38}$

\begin{tabular}{|c|c|c|}
\hline 項 & 強酸性カチオン交換縺維 & 強塩基性アニオン交換樹脂 \\
\hline 品 & IONEX TIN-110 & IONEX TIN-200 \\
\hline イオン交換 基 & スルオン酸基 & 第四アンモニウム塩基 \\
\hline 性 & $\begin{array}{l}{\left[-\mathrm{SO}_{3} \mathrm{H}\right]} \\
\text { 多芯海島型複合繊維 }\end{array}$ & 多芯海島型複合織維 \\
\hline 形 & 直径約 $40 \mu \mathrm{m}$ & 直径約 $40 \mu \mathrm{m}$ \\
\hline & 長さ $300 \mu \mathrm{m}$ & 長さ $500 \mu \mathrm{m}$ \\
\hline 総イオン交換容量 & 3. $0 \mathrm{mg}$ eq以上 $/ \mathrm{g}(\mathrm{dry})$ & 2. $0 \mathrm{mg}$ eq以上 $/ \mathrm{g}$ (dry) \\
\hline 耐 用 & $100^{\circ} \mathrm{C}$ 以下（H型） & $60^{\circ} \mathrm{C}$ 以下（OH型） \\
\hline & $120^{\circ} \mathrm{C}$ 以下 ( $\mathrm{Na}$ 型) & 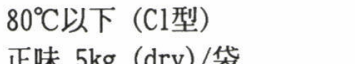 \\
\hline 梱 包 単 & 正味 5kg (dry)/袋 & \\
\hline
\end{tabular}

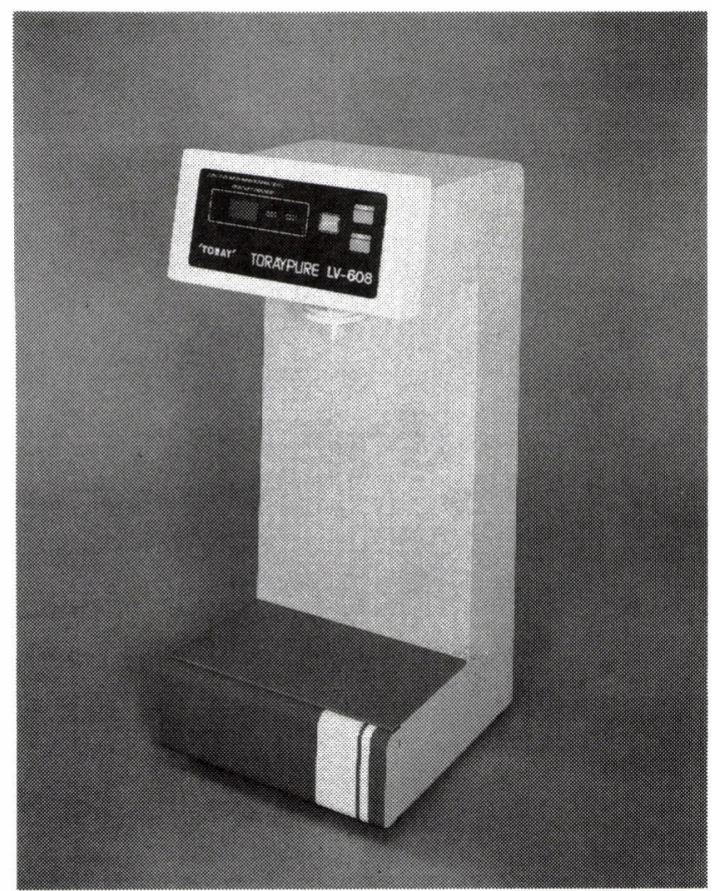

写真 37 小型超純水製造 トレピュア LV-608 （超純水採取量：0.8 1.2 l/min.）

参照）に使用されている ${ }^{137), ~ 141) 。 ~}$

イオン交換濾紙 RX-1 はイオンの捕捉速度が極 めて速く, 微量イオンを高精度で分析するのに向 いている。現在原子力発電所の水質管理に使用さ れており，その用途分野は拡大しつつある ${ }^{142)} 。$

イオン交換緘維は加工が容易で, 形態を様々に
変えうるので, 空気処理フィルターや, 反応蒸留 などの固体酸や固体塩基触媒として, また高分子 に対する高い吸着容量などの性質を利用した生理 活性物質の吸着固定化や, クロマト分離精製など への利用用途の拡大が考えられている ${ }^{137), ~ 139) ~-~ 140) 。 ~}$

以上の他, 1980年代末から, 日本原子力研究所 高崎研究所などでグラフト重合による各種繊維状 物質の機能化が研究され ${ }^{143)}$, 繊維状や中空糸状の イオン交換体やキレート体の製造と用途開発が熱 心に行われており，それぞれ成果を挙げている。

イオン交換瀻維やキレート纎維は, 従来の粒状 体のイオン交換樹脂のブレークスルーとして, そ の用途開拓が盛んに行われており, 需要は現在着 実に増加している状況で, 今後の発展は大変有望 と考えられる。

PWR原子力発電所の復水脱イオン装置処理水の純 度を飛躍的に高める改良再生システムが1984年か ら採用され始めた

PWR 型原子力発電所の復水は, 安全管理のため に水質基準が年々極めて厳しくなった。

そこで, オルガノ(森は, 復水脱イオン装置の再 生の際, 逆洗分離後の陽・陰両イオン交換樹脂の 各樹脂層に両樹脂の混合物が混入することを極力 防止することによって, 塩酸と水酸化ナトリウム による再生により, カチオン交換樹脂層中の $\mathrm{Na}$ 型 
樹脂 $(\mathrm{R}-\mathrm{Na})$ の生成と，アニオン交換樹脂層中の $\mathrm{Cl}$ 型樹脂 $(\mathrm{R}-\mathrm{Cl})$ の生成（相互污染）を極力回避す る改良再生方式を新しく開発した。

この改良型再生方式は 1984年に九州電力(森川内 原子力発電所 1 号機 $(890 \mathrm{MWe})$ に初めて採用され $た^{144)}$ 。

この改良型再生システムは，図 $3^{95)}$ に示すよう に，混合イオン交換樹脂を逆洗により分離する操 作を行い，かつカチオン交換樹脂層の再生を行う CT塔, 逆洗分離されたア二オン交換樹脂層の再生 を行う AT塔, 当該逆洗操作の際に分離してなか った両イオン交換樹脂の混合層を取り出して貯留 する HT塔（この混合層は次回の CT塔における逆 洗操作開始前に CT塔に返送する)，および再生済
カチオン交換樹脂とアニオン交換樹脂とを混合し て貯留し，次回の脱イオン用に直ちに役立つよう に待機させておく $M$ 塔などによって構成されてい $3^{95)}$ 。

この改良再生方式を採用した結果は, 表 4 に示 す通りで, 処理水の純度は飛躍的に向上し $た^{95), 144)}$ 。

即ち, 再生方式を改良再生方式に改造する前と 後亡では, 再生後のアニオン交換樹脂層中の $\mathrm{R}-\mathrm{Cl}$ の含有率が, 20〜 30\%から1〜3\%に激隇し，ま た力チオン交換樹脂層中の $\mathrm{R}-\mathrm{Na}$ の含有率も $0.2 \sim$ $0.4 \%$ から $0.1 〜 0.2 \%$ に半減した。

その結果, 改良再生方式に改造後は, 処理水中 $\mathrm{Cl}$ イオンは $0.1 \mu \mathrm{g} / 1$ が $1 / 5$ の $0.02 \mu \mathrm{g} / 1$ に滅少し

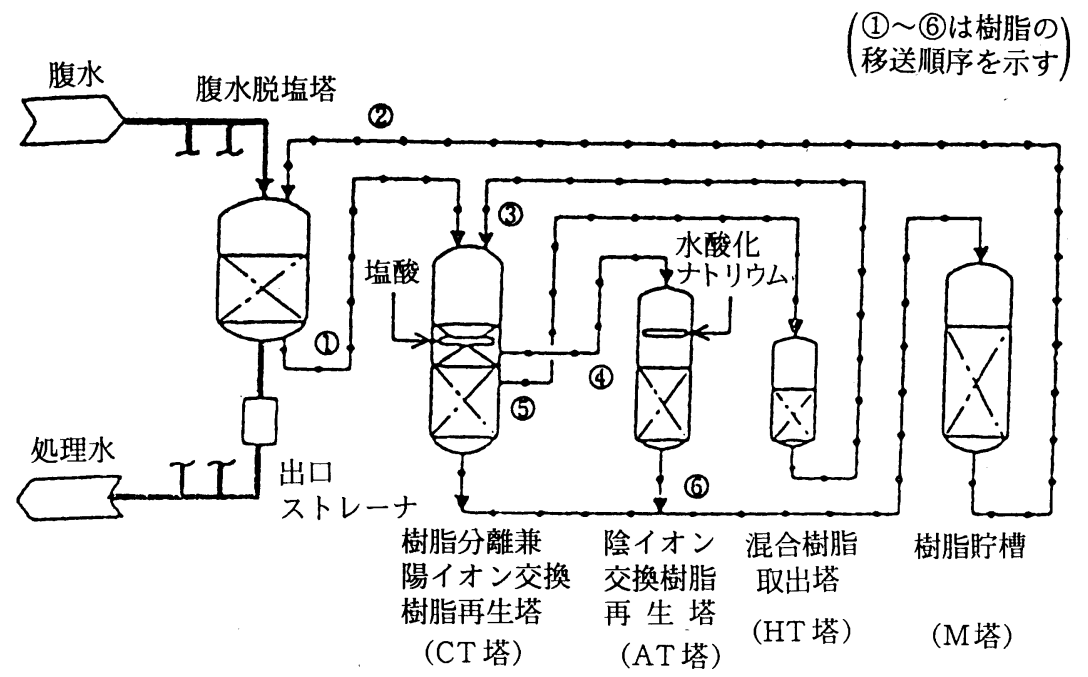

図3PWR用復水脱イオン装置の改良再生方式のフローシートの一例

表4 PWRの復水脱イオン装置出口水純度（再生方式改造前・後） (九州電力侏)川内原子力発電所 1 号機)

\begin{tabular}{|c|c|c|c|c|}
\hline 成 分 & 基準値 & 目標値 & 改造前 & 改造後 \\
\hline $\mathrm{Na}(\mu \mathrm{g} / 1)$ & $<0.06$ & $<0.02$ & 0.01 & 0.005 \\
$\mathrm{Cl}(\mu \mathrm{g} / 1)$ & $<0.15$ & $<0.05$ & 0.1 & 0.02 \\
$\mathrm{Na} / \mathrm{Cl}$ (モル比) & $<0.7$ & $0.5 \pm 0.2$ & 0.2 & 0.4 \\
\hline $\mathrm{R}-\mathrm{Na}(\%)$ & - & - & $0.2 \sim 0.4$ & $0.1 \sim 0.2$ \\
$\mathrm{R}-\mathrm{Cl}(\%)$ & - & - & $20 \sim 30$ & $1 \sim 3$ \\
\hline
\end{tabular}


て，水質目標值の $0.05 \mu \mathrm{g} / 1$ を十分下回る值となっ た。また, Naイオンは $0.01 \mu \mathrm{g} / 1$ が $1 / 2$ の $0.005 \mu \mathrm{g}$ $/ 1$ に減少して, 水質目標値の $0.02 \mu \mathrm{g} / 1$ をはるかに 下回る值となり, $\mathrm{Na} / \mathrm{Cl}$ のモル比は 0.2 から 0.4 に 上昇して，水質目標値の $0.5 \pm 0.2$ を確実に満足し て, 処理水に対する厳しい要求水質をすべてクリ アーすることに成功しだ'144)。

このことは，PWRの長期運転下における SG 伝 熱管やタービン材などの健全性を高め，プラント の信頼性向上に大きく寄与した。

現在では, この改良型再生方式は日本の全ての PWR 型原子力発電所の復水脱イオン装置に採用さ れている。

なお，この改良型再生方式は一部の BWR型原子 力発電所の復水脱イオン装置にも採用されてお り，また火力発電所の復水脱イオン装置にも採用 され始め，その第 1 号機は 1990 年に東京電力(㑣鹿 島火力発電所 1 号機 $(600 \mathrm{MWe})$ に採用された。

\section{0 年代}

\section{電気透析式連続イオン交換脱イオン装置の開発}

電気透析式連続イオン交換脱イオン装置は, ア ニオン交換膜とカチオン交換膜で構成する脱イオ ン室に, カチオン交換樹脂とアニオン交換樹脂の 混合樹脂を充填したもので, 電気透析式に陽極と 陰極に直接電流を通電しながら脱イオン室（希釈 室）に給水を導入して脱イオン水を採取し，給水 中の不純物イオンは濃縮して, 濃縮室から給水の 一部で流し出すことを基本とした, 非再生型の連 続式脱イオン装置である（図 4 参照 $)^{145)}$ - 146)。

この方式の装置は, 1986年に米国の Millipore Corp.が初めて開発し(商品名イオンピュア), 日 本では栗田工業(侏が 1988年にその販売権を得て発 売を開始した ${ }^{147)}$ 。しかし 1989年に Millipore Corp. がこのイオンピュアの工業用途水処理部門を米国 の Ionpure Technologies Corp. (IPT社) に売却した ので, 栗田工業(㑣)改めて IPT 社から日本国内の 総販売権をえて，1991年より処理量 1001 /hを越え

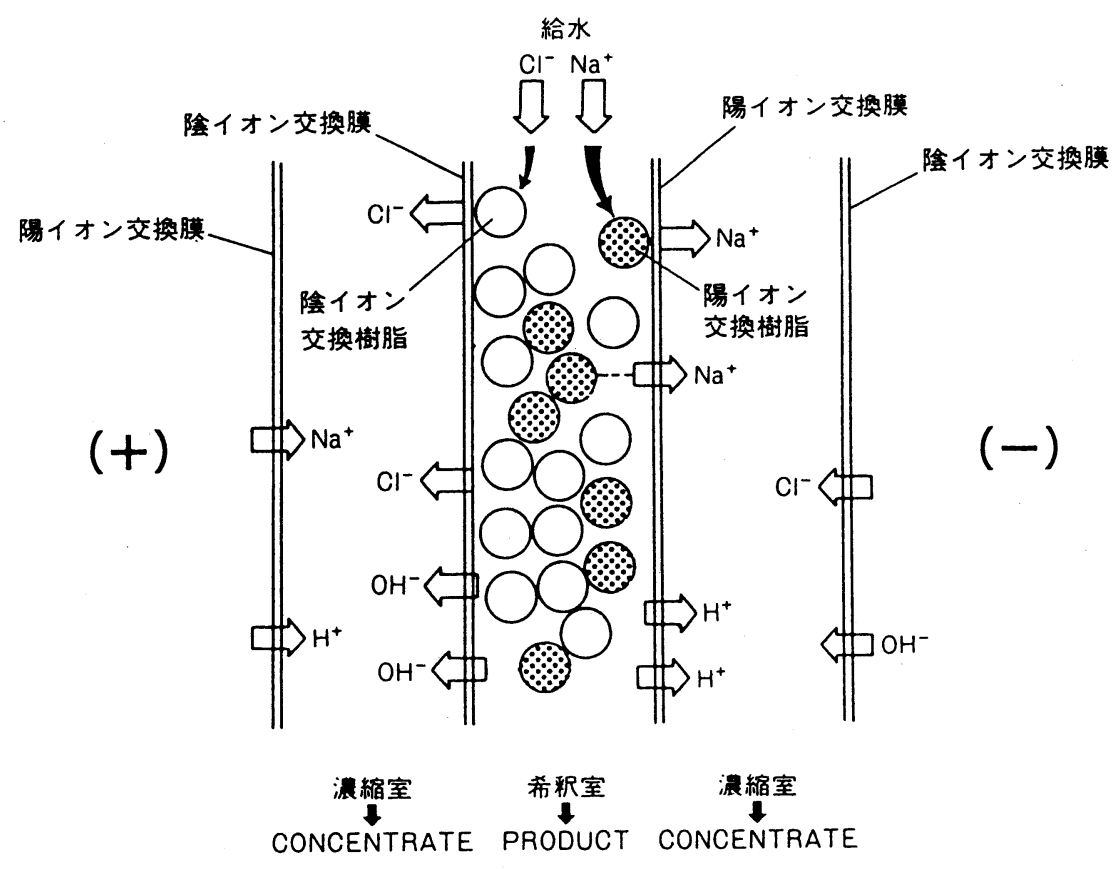

図4電気透析式連続イオン交換脱イオン法の原理図 
るプロセス用装置の販売を開始した（1001/h以下 の分析研究用小型装置は日本ミリポア(侏が販 壳 $)^{148)}$ 。

この装置は下記のような特徵を有しているとい われる(47), 1499。

1）イオン交換樹脂の再生が不要。

再生用薬品を使用せず，再生のために装置 を停止する必要も無く，人手がかからない。

2）再生処理設備が不要。

再生廃液が出ず，原水中の不純物は中性状 態で排出されるので, 廃水処理が不要とな る。

3）日常のメンテナンスが不要。

専門運転員が不要で，定期点検だけでよ い。

4）水質の変動に対応が可能。

給水の水質が変動しても, 電気透析の電圧 を変動することで，処理水水質の安定化を図 ることができる。

5）設置がコンパクトになる。

6）給水は十分上質なものが必要。

イオン交換膜やイオン交換樹脂の劣化と目 詰まり防止のため, 給水は十分上質でなけれ ばならず, 前処理装置として脱塩素装置, 保 安精密フィルター, および前脱塩用として逆 浸透装置の設置が必要となる。

日本では，栗田工業(株)の他に，下記のように才 ルガノ(株および日本錬水(侏がそれぞれ独自の装置 の開発を行っている。

\section{（1）栗田工業(侏)}

上記の連続脱イオン装置 $(\mathrm{CDI})$ を活用して, 原 水として市水を対象とし，脱塩素後， ROで前脱 塩し CDIでさらに高純な純水をうる小型高機能装 置（処理量 $0.12 \sim 2 \mathrm{~m}^{3} / \mathrm{h}$ ）として, 高品位連続純 水製造装置ピュアコンティ PC-ST シリーズ（150 $\sim 200 \mu \mathrm{S} / \mathrm{cm}$ の厚木市水を用いて処理水抵抗率 12 $\sim 15 \mathrm{M} \Omega \cdot \mathrm{cm}$ ) (医薬品原料水, 食品製造用水, 洗
浄用水，研究用水用など），およびさらにUV処理 装置，混床式ポリシャー，UF装置などで構成され るサブユニットで処理して超純水とする, 高品位 連続超純水製造装置をピュアコンティ PC-UP シ リーズ（同一市水を用いて処理水抵抗率 18.1 $18.2 \mathrm{M} \Omega \cdot \mathrm{cm}$ ）（半導体洗浄用水，精密部品洗浄用 水，研究用水用など）などを製造販売している (写真 38 参照 $)^{149)}$ 。

\section{（2）オルガノ(㧣)}

オルガノ(森が開発した方式は, 陰・陽両イオン 交換膜で構成する多数の脱イオン室（希釈室）に カチオン交換樹脂のみとアニオン交換樹脂のみを 交互に充填し，両イオン交換樹脂の混合物は用い ない方式で，いわば対床式とも云うべき電気透析 方式である。この方式は電気脱イオン式純水装置 EDI (Electro Deionization) と称せられる。

EDI装置 (写真 39参照) ${ }^{150)}$ の連続脱イオンの原 理を，原水中の不純物を食塩 $\left(\mathrm{Na}^{+} \mathrm{Cl}^{-}\right)$で代表し て，図5に示した。

図 5 において，カチオン交換樹脂を充填した脱 イオン室においては, 原水中の $\mathrm{Na}^{+}$は, カチオン 交換樹脂中の $\mathrm{H}^{+}$とイオン交換して樹脂に吸着され る。吸着された $\mathrm{Na}^{+}$は電流により陰極に引き寄せ られ，カチオン交換膜を通過し，ア二オン交換膜 に阻止され, 濃縮室より排出される。一方, 対イ オンの $\mathrm{Cl}^{-}$は，カチオン交換樹脂には吸着されない が，電流により陽極に引き寄せられ，アニオン交 換膜を通過し，カチオン交換膜に阻止され，濃縮 室より排出される。

また，アニオン交換樹脂を充填した脱イオン室 においては，原水中の $\mathrm{Cl}^{-}$は，アニオン交換樹脂中 の $\mathrm{OH}^{-}$とイオン交換して樹脂に吸着される。吸着 された $\mathrm{Cl}^{-}$は電流により陽極に引き寄せられ，アニ オン交換膜を通過し，カチオン交換膜に阻止さ れ, 濃縮室より排出される。一方, 対イオンの $\mathrm{Na}^{+}$は，アニオン交換樹脂には吸着されないが, 電流により陰極に引き寄せられ，カチオン交換膜 


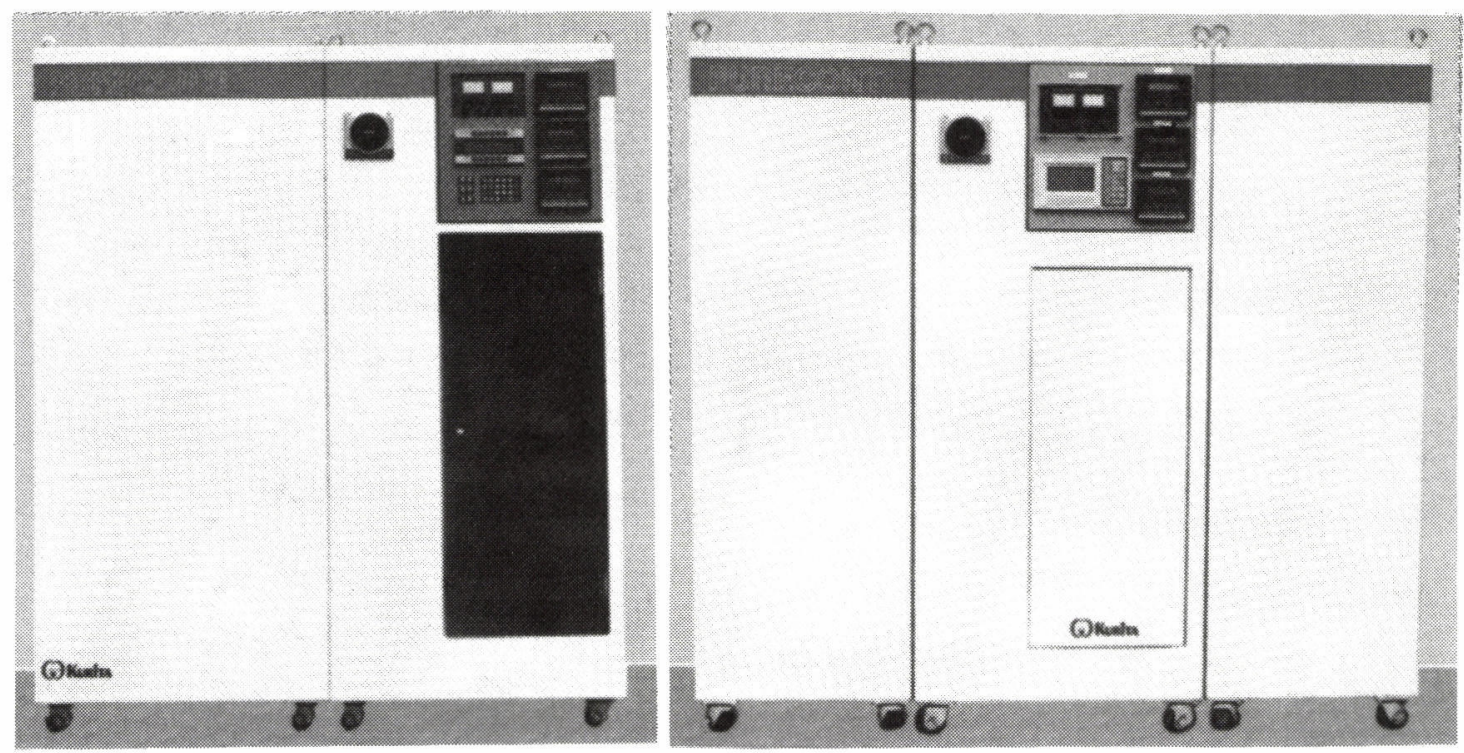

写真 38 ピュアコンティ PC-STタイプ（左側）と ピュアコンティ PC-UPタイプ（右側）

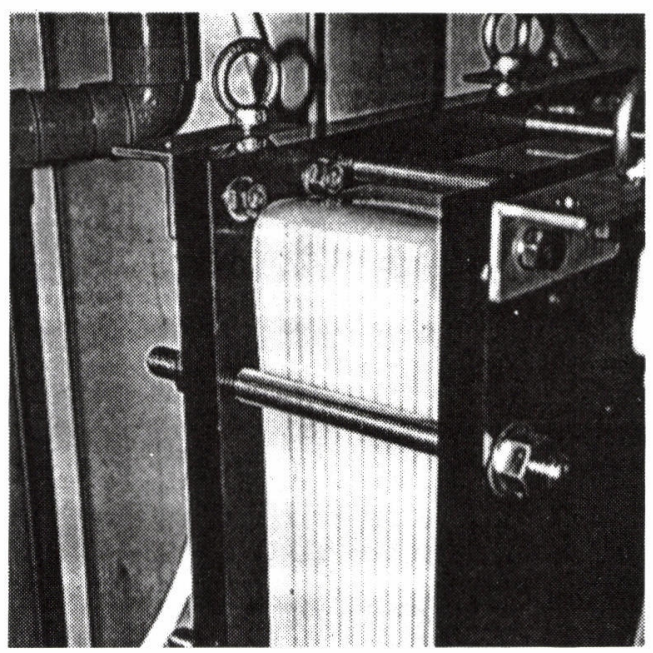

写真 39 EDI 装置のスタック

を通過し，アニオン交換膜に阻止され，濃縮室よ り排出される。

この両方の脱イオン室が対をなして並列に配列 される事により, 純水が処理水として得られ, 不 純物は濃縮水として排出される。

商品のスーパーデザリナー（写真 40 参照）は,
$\mathrm{RO}$ 装置を前脱塩装置として EDI装置と組み合わせ

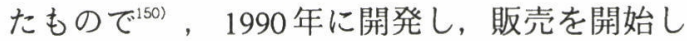
た。処理水容量は $0.5,1,2 \mathrm{~m}^{3} / \mathrm{h}$ の 3 機種である。

この EDI 装置の特徵は, 従来の混床樹脂使用の 場合の利点はほとんどすべて有するほか, 特にシ リカの除去率が EDI装置では $90 \%$ 以上と高い值を 示すことである ${ }^{151)}$ 。また，イオン交換膜の間には 陰, 陽イオン交換樹脂のそれぞれ単一物を充填 し，陰・陽両イオン交換樹脂の混合物を充填する ことがないから，イオン交換樹脂の充填や取り出 しが単純で容易と考えられる。

\section{（3）日本鍊水(侏)}

日本錬水(保は，この方式の純水製造装置として 連続再生式純水装置 CDS ユニットを開発し，これ を RO ユニットなどを前処理として連結した商品 Codes CDS シリーズを 1991 年から上市し $た^{(152)-153)}$ 。

CDS ユニットに使用するイオン交換樹脂は, 陰・陽両イオン交換樹脂の混合物で，イオン交換 膜は旭硝子が新たに開発した高強度の厚膜を使用 


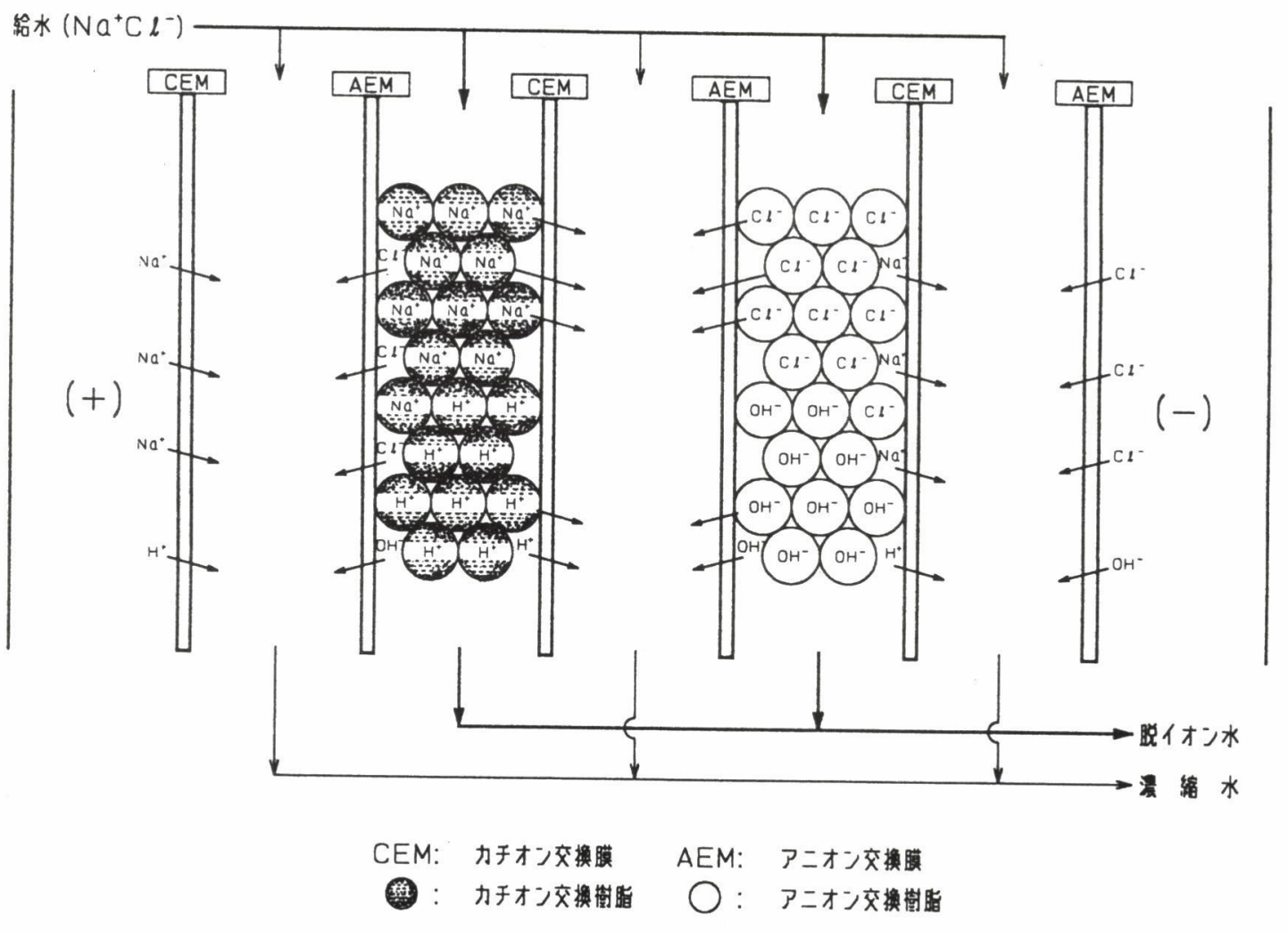

図5 EDI 装置の連続脱イオンの原理図

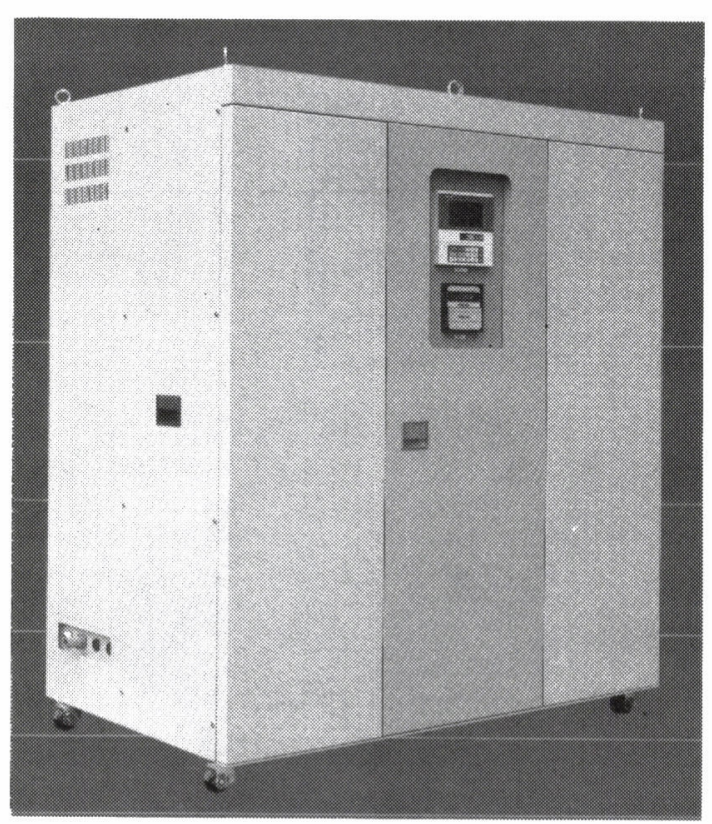

写真40 スーパーデサリナー
して，信頼性を高めたとしている ${ }^{152)}$ 。

処理水容量は $0.5,1,2 \mathrm{~m}^{3} / \mathrm{h}$ の 3 種類で, 処理水純 度は $3 \sim 15 \mathrm{M} \Omega \cdot \mathrm{cm}$ である ${ }^{153)} 。$

しかし最近は, 球状のイオン交換樹脂の代り に，陰・陽両イオン交換繊維の混合物を使用した 新商品を開発し，1993年より販売を始めた。この 新 CDS 装置の連続脱イオンの原理を, 原水中の不 純物を食塩 $\left(\mathrm{Na}^{+} \mathrm{Cl}^{-}\right)$で代表して, 図6に示し $た^{154)}$ 。

この商品は, 従来の球状イオン交換樹脂を用い たものに比し, 電極側へのイオンの移動速度を最 大限に大きくすることが可能となり，処理水水質 が飛躍的に向上して，常に高純度の純水を製造し 続けることが出来るようになった。それゆえ，現 在はこの新商品を主流としている ${ }^{154)}$ 。

新商品として, 小型の Labo Codesは, 処理水容 


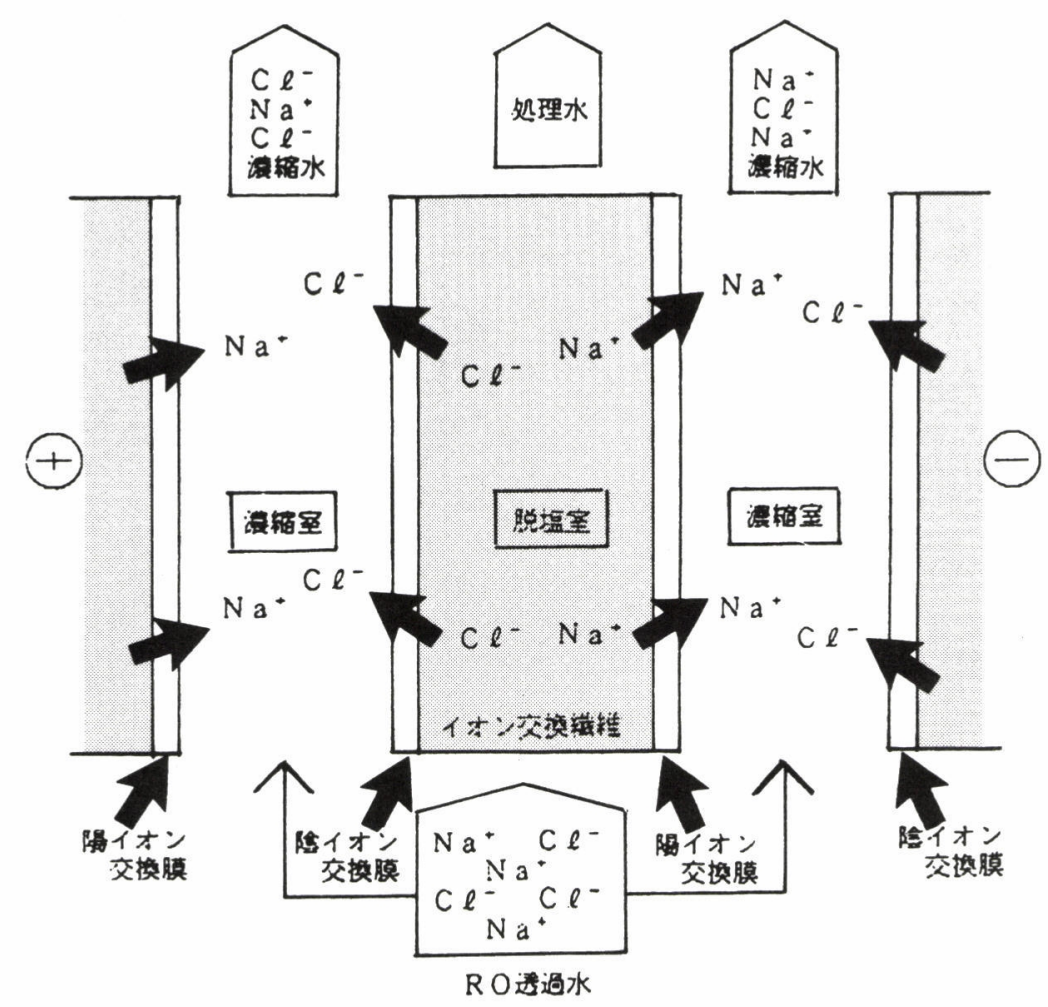

図6CDS 装置の連続脱イオンの原理図

量が 50 l/h (CDS-05型) と 100 l/h (CDS- 1 型)

の2機種, 工業用 Codesは, 処理水容量が $0.5 \mathrm{~m}^{3} / \mathrm{h}$ (CDS-5) , $1 \mathrm{~m}^{3} / \mathrm{h}(\mathrm{CDS}-10), 2 \mathrm{~m}^{3} / \mathrm{h}(\mathrm{CDS}-$ 20 ）の3機種の標準型装置があり（写真 41 参 照），それ以上の容量のものも製作販売してい $3^{154)}$ 。

処理粋純度は, 表 $5^{154)}$ に示すように, $12 \sim 17$ $\mathrm{M} \Omega \cdot \mathrm{cm}$ 高純度純水となる。

以上, 電気透析式連続イオン交換脱イオン装置 の開発状況を述べたが, この方式の脱イオン装置 は, 前処理としてR O装置を置くことが前提とな るので, $\quad 10 \sim 17 \mathrm{M} \Omega \cdot \mathrm{cm}$ の高品位純粋を再生しな いで採取するのに向いている。しかしそれ以上の 超純水之するには, 必ずイオン交換樹脂のカート リッジ型混床式ポリシャーで後処理することが必 要である。しかしいずれにしても,イオン交換体 を再生する必要はないので，これまでのように大

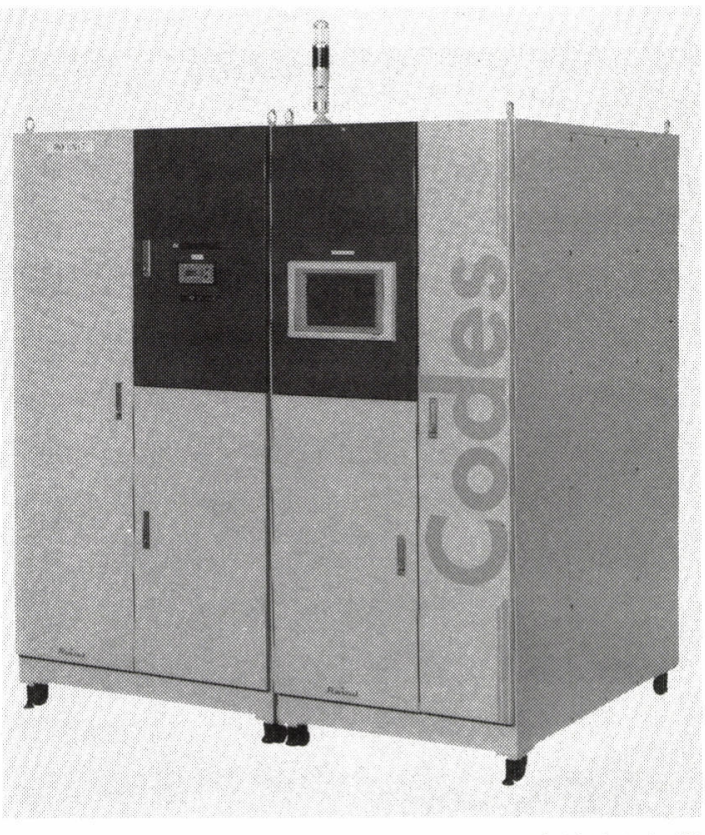

日本鍊水(株)提供

写真 41 Codes CDS-10（処理容量 $1 \mathrm{~m}^{3} / \mathrm{h}$ ） 
表 5 CODES（イオン交換織維使用）の運転データーの一例

（運転条件：電流密度 $40 \mathrm{~mA} / \mathrm{dm}^{2}$, 通水SV $50 \ell / \ell-V o l . h$ )

\begin{tabular}{|c|c|c|c|}
\hline 分 & 原 水 & RO出口 & CDS出口 \\
\hline 電気伝導率 $\left(\mu \mathrm{S} / \mathrm{cm}, 25^{\circ} \mathrm{C}\right)$ & 210 & $5 \sim 15$ & $0.083 \sim 0.059$ \\
\hline 電気抵抗率 $\left(\mathrm{M} \Omega \cdot \mathrm{cm}, 25^{\circ} \mathrm{C}\right)$ & & & $12 \sim 17$ \\
\hline$(\mathrm{mg} / \mathrm{l})$ & 7.6 & 0.7 & 0.05 以下 \\
\hline$(\mathrm{mg} / \ell)$ & 21.0 & 0.58 & 0.01 以下 \\
\hline$(\mathrm{mg} / \ell)$ & 0.2 & 0.05 以下 & 0.05 以下 \\
\hline
\end{tabular}

量の再生廃水の処理が不要となり, 純水採取運転 が連続的に簡単かつ容易に出来る利点がある。

次に, この電気透析装置の狭いイオン交換膜の 間に，イオン交換樹脂粒子を充填する代わりに, 前項で述べた直径が 10〜 $40 \mu \mathrm{m}$ の細いイオン交換 繊維を不織布，フエルト，布状などに加工して挿 入すれば，イオン交換体中のイオンの移動速度を 極めて速くし，しかもイオン交換体同士の接触 を, 粒子の場合の点接触から線接触や面接触にか えることが出来るので，電流の導通を良くし，電 気透析脱イオンを一段と効率のよいものとし，ま たイオン交換体の出し入れや充填状態の安定化に も役立ることが出来ると考えられる。

日本鍊水(侏が最近開発に成功した新 CDS 装置 は，まさにこの方に沿ったもので，イオン交換 繊維の新用途を開拓したものである。

擬似移動床式クロマトグラフィーによる多成分分 離技術の開発

イオン交換樹脂を使用した液体クロマトグラフ ィーは, 固定床式分離装置から擬似移動床式分離 装置へと進歩してきた。しかし擬似移動床式分離 装置は，2成分の分離は出来ても，1回だけの分離 または 1つの分離システムだけでは，3成分以上の 分離は原理的に不可能であった。

オルガノ(㑣)は 3 成分以上の分離を 1 つの分離シス
テムだけで実施出来る “新 JO方式式クロマト分離 システム”を独自に開発して，1990年に上市し た。

この新分離システムは, 固定床式と擬似移動床 式クロマト分離装置のそれぞれの特長を生かして 有機的に組み合わせて完成した多成分分離システ ムで, 連続運転が可能で, 擬似移動床式クロマト 分離装置の高度な分離性能を損なうことなく，三 つ以上の製品区分に分けることの出来る画期的な 分離システムである ${ }^{155)-159) 。 ~}$

そのシステムの原理を図 7 と図 8 に示 す $^{157)-159)}$ 。ただし分離の対象成分を A， B，Cの 3成分とし，イオン交換樹脂との親和性の強さを $\mathrm{A}$ $<\mathrm{B}<\mathrm{C}$ とする。 $\mathrm{F}$ は原液， Dは溶離液とする。 装置としては, 擬似移動床式クロマト分離装置 に，さらに成分 $\mathrm{B}$ の出口を追加し，この時円環状 の循環の流れを区切ることの出来る装置を考え る。

図 7 において，溶離液と原液を供給しながら， 固定床方式の場合之同様に，成分 B を先ず抜き出 す（4成分分離の時は成分 $\mathrm{B} 1, \mathrm{~B} 2$ を抜き出す）。 その後, 図 8 に示す様に, 原液の供給を停止 し，擬似移動床式クロマト分離装置の場合之同様 に，液体の出入口 D, A， Cを切り替えながら成 分 $\mathrm{A}, \mathrm{C}$ を連続的に抜き出す。この時, 各液体出 入口の移動速度は, 成分 B の移動速度と同じにな 


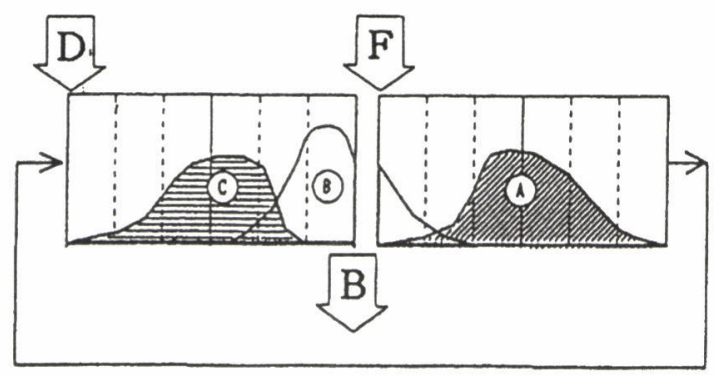

図7新JO 方式クロマト分離装置における各成分の 挙動(1)（固定床方式部）

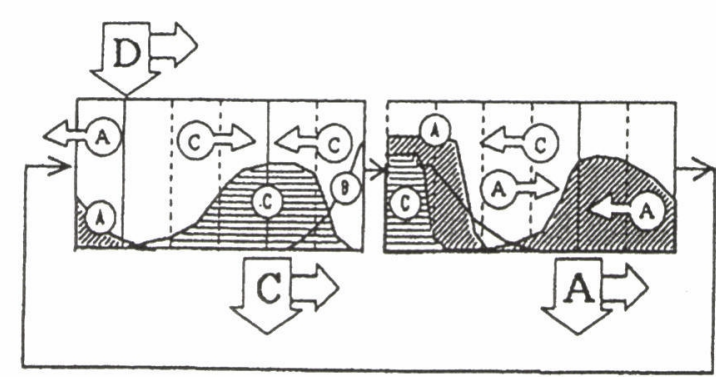

図8 新JO方式クロマト分離装置における各成分の 挙動(2)（原液供給停止・擬似移動床式部）

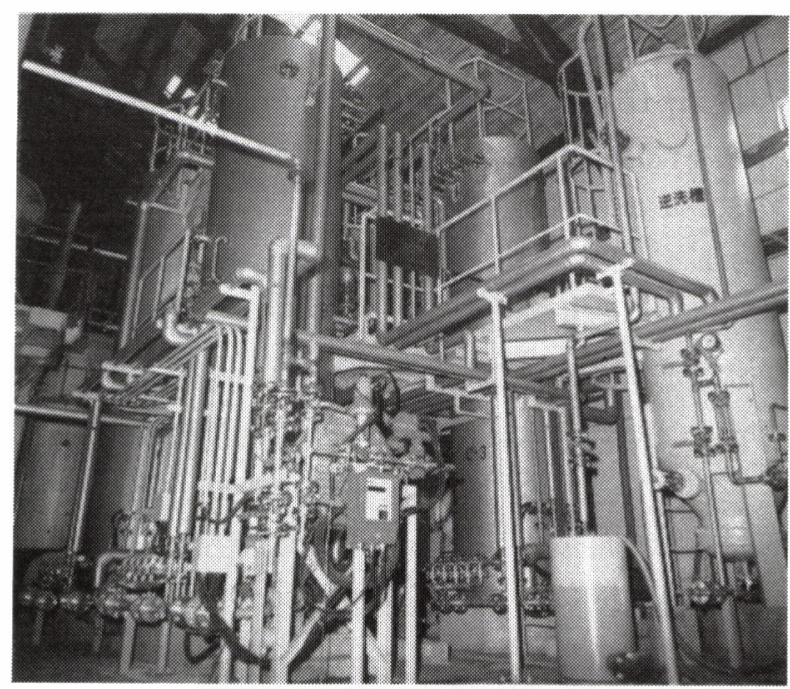

写真 42 新 JO 方式多成分クロマト分離装置 (イオン交換樹脂充填量 $10 \mathrm{~m}^{3}$ )

\section{るように運転する。}

液体の出入口 D, A, Cが図 7 の位置まで一巡 したら，再び図 7 に示した操作を行い，成分 B（B1，B2）を抜き出す。

このような図 7 と図 8の操作を繰り返し行うこと により，成分 A， B（B1，B2），Cを連続運転に より分離する。

世界初の新 JO方式3成分クロマト分離装置は, オルガノ(株によって 1991 年に第 1 号機が設置され て稼働を始めた（写真 42 参照） ${ }^{156) .158)}$ 。

また本格的な新 JO方式 4成分クロマト分離装置
は，オルガノ(株)と日本甜菜製糖(㑣)の共同研究によ って, パイロットプラントを用いてビート糖蜜を 用いて分離試験を行い，同年に本装置がオルガノ (侏によって日本甜菜製糖(㑣)士別工場に建設され， 稼動が開始された

その共同研究は, クロマト分離用に開発された 均一粒径のゲル型強酸性カチオン交換樹脂アン バーライト CG 6000 ( $\mathrm{Na}$ 型) を使用して, 新 JO方 式により, ビート糖蜜中のラフィノーズ，スク ロース，単糖類およびベタインの 4 成分の分離試 験を行い，従来の擬似稼働床式分離システム（新 
MCI 方式）と比較した。試験結果の一部を表 6 に 示す ${ }^{159)-160) 。 ~}$

表 6よりビート糖蜜中の 3成分は（単糖類はその ままでは利用しないので評価の数值からは除外し た), 純度 72〜 85\%, 回収率 69〜93\%で，ほぼ良 好に分離され，従来の擬似稼㗢床式クロマト分離 システムより格段に分離性能が優れていた。

このような分離方式に，粒状のイオン交換体の 代わりに交換繊維やその加工物を使用する試みは まだ行われていないようであるが，イオン交換瀻 維は粒状のイオン交換体に比し, 反応速度や拡散 速度が極めて速く，また分離段数を大とすること も考えられれるので, 例えばイオン交換フェルト を移動させる移動床方式や，イオン交換繊維モジ ユールを用いた擬似移動床分離方式などの研究 は，興味あるテーマとなるのではなかろうか。

以上，日本におけるイオン交換技術の発展を， 年代を追って述べたが, 敗戦後の廃墟と窮乏の中
から日本を再建し，豊かで平和な社会を築き上げ るために，イオン交換技術は色々な分野で陰に陽 に大きな貢献をしたといえよう。

イオン交換体がなぜこれほど多方面に急速に役 立てることが出来たかといえば，それは，“自然 界には水に溶けない酸や塩基が存在しなかった” からだということが出来よう。その存在を可能と したのは，今世紀に入ってからの高分子化学の急 速な発展によるものである。

イオン交換体は不溶性の酸・塩基・塩という最 も単純な機能性高分子にすぎないものであるが, その学問的基礎と応用は，まだまだはかり知れな い深さと広さをもっている。今後は，さらに他の 機能性高分子の発展へと益々その範囲を広げ，末 知の学問の探究之, 未踏の応用分野の開拓が大い に成されんことを期待してやまない。

私事で恐縮であるが, 小生はイオン交換樹脂と 出会ってから 35 年間, この画期的な化合物とその

表 6 新JO方式クロマト分離装置によるビート糖蜜中の 4 成分分離 のパイロット規模の試験データー

(1) 分離条件

\begin{tabular}{|c|c|c|c|}
\hline \multicolumn{4}{|c|}{$\begin{array}{l}\text { 分離カラム : アンバーライト CG 6000 (Na型)(架橋度6\%)使用 } \\
\text { 溶 離 液 : 脱塩水 }\end{array}$} \\
\hline 原液濃度 & $(\mathrm{Bx} \%)$ & 60.9 & \\
\hline 原液組成 & (DS\%) & 非糖類（塩類, 色度等） & 4.6 \\
\hline & & ラフィノース & 18.1 \\
\hline & & スクロース & 55.8 \\
\hline & & 単糖類（葡萄糖, 果糖糖等） & 10.5 \\
\hline & & ベタイン & 11.0 \\
\hline 原液供給量 & $(\mathrm{BV} / \mathrm{h})$ & 0.0290 & \\
\hline 溶離液供給量 & $(\mathrm{BV} / \mathrm{h})$ & 0.1952 & \\
\hline
\end{tabular}

(2) 分離結果

（A区分にはラフィノースの他に非糖類も含む）

\begin{tabular}{|l|l|c|c|c|}
\hline 区 分 & \multicolumn{1}{|c|}{ 成 分 } & $\begin{array}{c}\text { 濃 } \\
(\mathrm{Bx} \%)\end{array}$ & $\begin{array}{c}\text { 純 } \\
(\%)\end{array}$ & $\begin{array}{c}\text { 回収率 } \\
(\%)\end{array}$ \\
\hline $\mathrm{A}$ 区分 & ラフィノース & 8.5 & 71.6 & 69.1 \\
\hline $\mathrm{B} 1$ 区分 & スクロース & 24.6 & 85.4 & 93.2 \\
\hline $\mathrm{B} 2$ 区分 & 単糖類 & 4.2 & 62.3 & 59.2 \\
\hline C区分 & ベタイン & 3.5 & 73.5 & 90.0 \\
\hline
\end{tabular}


応用技術を少しでも日本の復興に役立てたい一心 で，日夜を夢中に過ごしてきた。しかし，1970年 代末に到って，その役目は終わりとなった。ま た，小生が活動の足場としたオルガノ(籼も，イオ ン交換装置や水処理の有力会社として立派に発展 したので，会社役員を自ら退いて後進に道を開 き, 爾後は自由な立場でコンサルティングを行 い, また国際コミュニケーションに微力を尽くす ことが出来る様にした。

\section{謝 辞}

本総説を執筆するにあたり, 次に示す多くの会 社（五十音順）から, 日本におけるイオン交換技 術の歴史的発展および最新の情報に関する数多く の論文, 資料, カタログ, および貴重な写真など を御提供頂いて, 御協力賜ったことに深く感謝す る。

\section{旭化成工業株式会社}

旭硝子株式会社

オルガノ株式会社

栗田工業株式会社

昭和電工株式会社

株式会社住化分析センター

住友化学工業株式会社

東京有機化学工業株式会社

東レ株式会社

徳山曹達株式会社

野村マイクロ・サイエンス株式会社

ニチビ株式会社

日本甜菜製糖株式会社

日本天然瓦斯興業株式会社

日本鍊水株式会社

前澤化成工業株式会社

三菱化成株式会社

三菱化成テクノエンジニアリング株式会社 （元菱化テクノ株式会社）

\section{文献}

118）赤松不二男, “実績 10 年, TI 美浦工場の排水ク ローズド・システム”, NIKKEI MICRODEVICES, 1990 年 11 月号, 153 160.

119）清水博, “工業用のきれいな水づくり”,「きれい な水づくり」セミナーテキスト，侏技術情報セ ンター主催（東京）, 1988年 1 月 29 日.

120）中村光男, “2. 半導体製造工場におけるゼロエ フルエントシステム”, 最新の膜処理技術とその 応用, 清水博, 西村正人編集, (侏フジ・テクノ システム (1984) pp.532 534.

121）オルガノ椒カタログ，“超純水製造システム”, Cat.No.A-51-3 (1991 年 12 月).

122）栗田工業(侏カタログ, “クリタの超純水システム” (PS-07585L).

123）今泉正文, “3. 電子工業排水の再利用”, 膜処理 技術大系, 下巻（応用・資料編）, 中垣正幸監修, 清水博編集 (幹事), (森フジ・テクノシステム (1991) pp.399 401.

124）藤井信夫，“分けにくいものを速やかに一イオ ン交換緎維”, 化学装置, 1987年2月号, 69 71.

125）堀江広, “イオン交換緎維——その特徵と使用 例—”，造水技術, 15(2), 59 62 (1989).

126）清水博, “イオン交換繊維の応用技術”，「吸着 材の特性と最近の利用技術セミナー」テキス ト，侏エヌ・ティー・エス主催（東京）１989年 8 月 $24 \sim 25$ 日.

127）山田節夫，“第 6節 イオン交換䄉維， 2. 侏)二チ ビ製”， pp.323 329；“第 8節 キレート緎維,

2. 俶)二チビ製”, pp.398 400, 清水博監修「吸 着技術ハンドブック」，侏エヌ・ティー・エス (1993).

128）侏ニチビカタログ，“ニチビイオン交換瀻維”。

129）山崎和夫, 清水博, “5.1 焼成ポリビニルアル コール系イオン交換綫維による脱臭”，清水博 監修「吸着技術ハンドブック」，侏エヌ・テ イー・エス (1993) pp.323 329.

130) 清水博, 太期敏之, 東秀夫 (Rohm and Haas Co.), "Method for Treatment of Aqueous Solution With Ion Exchange Fibers", USP 4313832(1982).

131）清水博, 杵渕欽治, 太期敏之, 折橋譲（オルガ ノ(俶)，“イオン交換樹脂微粒子とイオン交換緎 維とを用いた水溶液の処理方法”，日本特許 
1487754 (1989).

132）住友化学工業(侏)資料，“高性能イオン交換紙一 エクスパピール”(1984年).

133）(株住化分析センターカタログ, “高性能工業用及 び分析用イオン捕捉滤紙——クスパピール”.

134）千貫高志, 松本孝春, 青柳正也, “2.1 分析 ・ 試験用製品, (4)住友化学工業(侏製”, 上巻（基 礎・製品編）pp.246 247；“4. (2)高性能イオン 捕捉濾紙エクスパピールによる微量金属の分 析”，下巻（応用・資料編） pp.596 598，膜処 理技術大系, 中垣正幸監修, 清水博編集（幹 事)，(侏フジ・テクノシステム (1991).

135）東レ(侏カタログ，“IONEX緎維状イオン交換 体”（1990年).

136）飯田汎, “織維状吸着剂について一ポリスチレ ン系㵶維状イオン交換体を中心に——，「吸着 剂の特性と最近の利用技術セミナー」テキス ト，(侏エヌ・ティー・エス主催（東京），1989年 8 月24 25日。

137）吉岡敏雄, 平田奈美, “第6節 イオン交換緘 維，1．東レ(侏製”，pp.315 322; “第8節 キ レート繊維，1．東レ(侏製”，pp.395 397，清 水博監修「吸着技術ハンドブック」，(侏)エヌ・テ ヘー・エス (1993)

138）東レ(㧣の最近の資料による.

139) M. Henmi, S. Mori, Y. Noguchi, T. Yoshioka, "Application of Ion Exchange Fiber IONEX to Precoating Material and Filter Paper", 1991 JAIF International Conference on Water Chemistry in Nuclear Power Plants, pp.788 703 (1991); “イオ ン交換織維 IONEXのプリコート材及びろ紙への 応用”（上記報文の和文）。

140) K. Otoha, Keynote Lecture, 1991 JAIF International Conference on Water Chemistry in Nuclear Power Plants (1991); O. Amano, et al, ibid, pp.85 (1991)

141）東レ(侏カタログ，超純水製造装置トレピュア.

142）東レ(侏)技術資料，“金属イオン捕捉・分析用，東 レイオン交換滤紙 (IONEX 使用)RX-1"(89W01).

143）須郷高信，“3. 放射線グラフト重合によるイオ ン交換緎維”，清水博監修「吸着技術ハンドブッ
ク」，侏エエ・ティー・エス (1993) pp.330 337.

144）井地輝雄，児玉英男，小池正実，土居将能，谷 口真, 香川喬, 竹内宏, “川内原子力 1 号機試運 転時の2 次系水質管理”，火力原子力発電， 36 (6), 585 599 (1985).

145）出口智章, “非再生型連続純水製造装置の原理と 応用”, 「日米超純水テクノロジー'90セミ ナー」テキスト，㑣エヌ・ティー・エス主催（東 京，1990年9月 13 14日。

146）栗田工業(侏技術資料，“CDI”(2700b).

147）日本工業新聞, 1988 年 2 月 29 日.

148）化学工業日報，1990年 11 月 28 日.

149）栗田工業(侏カタログ，“高品位連続純水製造装置 ピュアコンティシリーズ”.

150) オルガノ(侏カタログ, “スーパーデサリナー” (1990年9月).

151）オルガノ(侏技術資料，“スーパーデサリナー説明 資料”(1991年 1 月).

152）化学工業日報，1991 年 5 月 23 日.

153）日本鍊水(侏)タログ, “標準型連続再生式純水装 置 Codes CDS シリーズ”

154）日本鍊水(侏)の最近の資料による.

155）増田隆之, “擬似移動層で多成分を分ける新 J O 方式クロマト分離装置の開発”， New Food Industry, 33 (12), 64 69 (1991).

156）オルガノ(侏カタログ， New Simulated MovingBed System for Fractionation of Multicomponent Mixture" (1992).

157）オルガノ(侏技術資料，“擬似移動層式クロマトに よる多成分分離技術”。

158）堀江正治，園部とおる，“第3節 糖類の多成分 クロマト分離技術”，清水博監修「吸着技術ハン ドブック」，(侏エヌ・ティー・エス (1993) pp.617 624.

159）松田文彦，園部とおる，金子菊造，増田隆之， “新しいクロマト分離システムとイオン交換樹 脂”, 日本イオン交換学会誌, 14(1), 65 72 (1992).

160）井上政尚, 藤崎裕之, 鎌田 隆, 川本常美, 佐 山晃司（日本甜菜製糖(侏)，松田文彦，園部とお る，増田隆之，金子菊造（オルガノ(侏)，第 80 回 製糖技術研究会講演要旨 1 4 (1992). 